\title{
SPATIAL VARIABILITY OF SARS-CoV-2 INFECTIONS IN THE SILESIAN VOIVODESHIP, POLAND
}

\section{TERYTORIALNE ZRÓŻNICOWANIE SYTUACJI EPIDEMIOLOGICZNEJ ZAKAŻEŃ WIRUSEM SARS-CoV-2 W WOJEWÓDZTWIE ŚLĄSKIM*}

${ }^{1}$ Medical University of Silesia, Faculty of Medical Sciences in KatowiceDepartment of Epidemiology

${ }^{2}$ State Sanitary Inspection, Provincial Sanitary And Epidemiological Station in Katowice

'Śląski Uniwersytet Medyczny, 1 Wydział Nauk Medycznych w Katowicach, Katedra i Zakład Epidemiologii,

${ }^{2}$ Państwowa Inspekcja Sanitarna, Wojewódzka Stacja Sanitarno-Epidemiologiczna w Katowicach

\section{ABSTRACT}

INTRODUCTION. SARS-CoV-2 (severe acute respiratory syndrome coronavirus 2) and related to infection COVID-19 (coronavirus disease 2019) remain a new and global challenge for public health. Due to the location, specifics of employment, and the high density of population in the Silesia voivodeship it is appropriate to study the available epidemiological data in a region with a potentially higher risk of infection.

MATERIALS AND METHODS. In the descriptive model of the study, data on the number of infected, hospitalized, and dead people due to SARS-CoV-2 infection were analyzed. The source of information was daily reports conducted by the Provincial Sanitary and Epidemiological Station in Katowice, in the period from March 5 to August 18, 2020.

RESULTS. Results of antigenic molecular tests for SARS-CoV-2 infection in the Silesian voivodeship indicate that in the first half of 2020 , the infection rate was approximately $5 \%$ and the symptomatic form of the disease was approximately $20 \%$.

CONCLUSIONS. The analysis of the frequency of infection and mortality in the poviats reveals a large variation in the occurrence of both phenomena, but the explanation of this difference is not possible due to the descriptive nature of the analysis and the secondary form of epidemiological data.

Keywords: SARS-CoV-2, epidemiological situation, the Silesian voivodeship

\section{STRESZCZENIE}

WSTĘP. Zakażenie wirusem SARS-CoV-2 i związana z nim choroba COVID-19 stanowią nowe, globalne wyzwanie dla zdrowia publicznego. Z uwagi na lokalizację i specyfikę zatrudnienia oraz duże zagęszczenie liczby mieszkańców w województwie śląskim, celowe jest badanie dostępnych danych epidemiologicznych w regionie o potencjalnie większym ryzyku zakażenia.

MATERIAŁ I METODY. W modelu badania opisowego przeanalizowano dane o liczbie zakażonych, liczbie zgonów i osób hospitalizowanych w związku z zakażeniem SARS-CoV-2. Źródłem informacji były dzienne raporty prowadzone przez Wojewódzką Stację Sanitarno-Epidemiologiczną w Katowicach, w okresie od 05 marca do 18 sierpnia 2020 roku.

WYNIKI. Wyniki antygenowych badań molekularnych w kierunku zakażenia wirusem SARS-CoV-2 w województwie śląskim wskazują, że w pierwszym półroczu 2020 roku częstość zakażeń kształtowała się na poziomie około 5\%, a częstość objawowej postaci choroby na poziomie około $20 \%$.

\footnotetext{
*Project „The prevalence and risk factors of SARS-CoV-2 infection in the population of the Upper Silesian Agglomeration in 2020/ Badanie jest finansowane w ramach projektu „Rozpowszechnienie, przebieg i czynniki ryzyka zakażenia wirusem SARS-CoV-2 w populacji Aglomeracji Górnośląskiej w 2020 roku" ze środków Agencji Badań Medycznych, Projekt nr 2020/ABM/COVID19/0044.
}

(C) National Institute of Public Health - National Institute of Hygiene / Narodowy Instytut Zdrowia Publicznego - Państwowy Zakład Higieny 
WNIOSKI. Analiza częstości zakażeń oraz śmiertelności w układzie terytorialnym województwa (powiaty) ujawnia duże zróżnicowanie występowania obu zjawisk, przy czym wyjaśnienie tego zróżnicowania nie jest możliwe ze względu na opisowy charakter analizy oraz tzw. wtórną postać danych epidemiologicznych.

Slowa kluczowe: SARS-CoV-2, sytuacja epidemiologiczna, województwo śląskie

\section{INTRODUCTION}

SARS-CoV-2 infection (severe acute respiratory syndrome coronavirus 2) and the associated with it disease COVID-19 (coronavirus disease 2019) remains a new global challenge for public health on a scale unprecedented in recent history. It forces urgent political decisions and regulations of social life aimed to reduce the negative effects of the pandemic (1). Rational preventive measures require the recognition of the current epidemiological situation. The adopted method of registering COVID-19 cases in Poland includes positive results of antigenic molecular tests carried out by the method of reverse transcriptase-polymerase chain reaction (RT-PCR), the number of deaths due to disease, and the number of convalescents. This obligation rests with the State Sanitary Inspection, and until June 11, information was provided twice a day (around 10:00 a.m. and 5:30 p.m.), and currently, the data is communicated only once a day in the afternoon (2).

The Silesian Voivodeship is a region of Poland with the highest population density, with the value at the level of 366 persons $/ \mathrm{km}^{2}$, with the average level of 123 persons $/ \mathrm{km}^{2}$ in Poland (3). It is also a highly industrialized region, here are located large industrial plants, including the mining industry and plants cooperating with the mining industry. An international airport (Katowice Pyrzowice) is also located in the region, serving nearly 5 million passengers in 2019, with a significant reduction in passenger traffic to 1.08 million in 2020 (4). Numerous communication routes of road traffic cross here, the region is inhabited by 4.5 million people, which is approx. $11.8 \%$ of the country's population (5). Therefore, it can be expected that due to its specificity, the Silesian Voivodeship is a region with a higher risk of transmission of the SARS$\mathrm{CoV}-2$ virus, which is mainly transmitted through direct contact or by droplets (6). Presented arguments revealed that the picture of the COVID-19 epidemic in the Silesian Voivodeship can be treated, on a national scale, like an increased risk scenario, which justifies a detailed study of the available epidemiological data. Therefore, an analysis was undertaken to describe the COVID-19 epidemic situation from the beginning of March to August 2020 in the Silesian Voivodeship.

\section{WSTEP}

Zakażenie wirusem SARS-CoV-2 (severe acute respiratory syndrome coronavirus 2) i związana z nim choroba COVID-19 (coronavirus disease 2019) stanowią nowe, globalne wyzwanie dla zdrowia publicznego w skali niespotykanej w najnowszej historii. Wymusza ono pilne decyzje polityczne oraz dalekosiężne regulacje życia społecznego, ukierunkowane na ograniczenie negatywnych skutków pandemii (1). Podejmowanie racjonalnych działań profilaktycznych wymaga rozpoznania aktualnej sytuacji epidemiologicznej. Przyjęty w Polsce sposób rejestrowania zachorowań na COVID-19 sprowadza się do raportowania wszystkich wykonanych, w tym pozytywnych wyników antygenowych badań molekularnych prowadzonych metodą reakcji łańcuchowej polimerazy z odwrotną transkryptazą (RT-PCR), liczby zgonów z powodu tej choroby oraz liczby ozdrowieńców. Obowiązek ten spoczywa na Państwowej Inspekcji Sanitarnej, przy czym do dnia 11 czerwca informacje podawano dwukrotnie w ciągu dnia (około 10:00 rano i 17:30 po południu), a obecnie dane są komunikowane jedynie raz dziennie w godzinach dopołudniowych (2).

Województwo śląskie jest regionem Polski o największej gęstości zaludnienia, z wartością wskaźnika na poziomie 366 osób $/ \mathrm{km}^{2}$, przy średnim poziomie dla Polski wynoszącym 123 osoby $/ \mathrm{km}^{2}$ (3). Jest to również region silnie uprzemysłowiony - tutaj zlokalizowane są duże zakłady przemysłowe obejmujące przemysł wydobywczy i zakłady kooperujące $\mathrm{z}$ górnictwem. W regionie znajduje się także międzynarodowy port lotniczy Katowice Pyrzowice obsługujący w 2019 roku blisko $5 \mathrm{mln}$ pasażerów, przy czym w 2020 roku odnotowano znaczne zmniejszenie ruchu pasażerów do poziomu 1,08 mln osób (4). Tutaj krzyżują się liczne szlaki komunikacyjne ruchu drogowego, region zamieszkuje 4,5 mln osób, co stanowi ok. 11,8\% populacji całego kraju (5). Można zatem oczekiwać, że z uwagi na swoją specyfikę, województwo śląskie jest regionem o wysokim ryzyku możliwości transmisji wirusa SARS-CoV-2, który w głównej mierze przenosi się poprzez kontakt bezpośredni lub drogą kropelkową (6). W świetle przytoczonych danych obraz epidemii COVID-19 w województwie śląskim można traktować, w skali kraju, jako scenariusz zwiększonego ryzyka, co z kolei uzasadnia szczegółowe badanie dostępnych danych. W związku z tym podjęto analizę, której celem było zebranie i opis sytuacji epidemicznej 


\section{MATERIAL AND METHODS}

In the model of descriptive epidemiological study, a secondary type of data on the number of infected, deaths, and people hospitalized due to SARS-CoV-2 was used. The source of information was daily reports conducted by the Provincial Sanitary Epidemiological Station in Katowice and its subordinate poviat stations. Obtained data included sex, age, and place of residence, as well as the likely circumstances of infection as determined by the epidemiological investigation. The study takes into account only the first-time positive results of the RT-PCR test for SARS-CoV-2 in the inhabitants of the Silesian Voivodeship, including employees of the mining industry, collected under the so-called screening tests. The analyzed data, presented concerning particular districts, represent the period from March 5 to August 18, 2020. The study will be continued until February 2021 and the final report will be completed with the appropriate results.

\section{RESULTS}

In the analyzed period, 19,242 cases of positive molecular tests for SARS-CoV-2 infection were registered in the Silesian Voivodeship. During this time, 390,834 tests were performed and thus the percentage of positive tests was $4.9 \%$. Men were twice as likely to be infected as women, $64.7 \%$ and $35.3 \%$, respectively. The average age of those who were positive is $42.9+/-18.0$ years, and the median is 41 years. Figure 1 shows the percentage share of the died, convalescents, and the so-called active cases among people with a positive RT-PCR test (as of August 18, 2020). Concerning people infected with the SARS$\mathrm{CoV}-2$ virus, the definition of the case was based on the decision of sanitary supervision assumed that convalescents were people with positive results, in whom two consecutive results of RT-PCR test were negative. On the other hand, active cases are people
COVID-19 w okresie od początku marca do sierpnia 2020 roku w województwie śląskim.

\section{MATERIAŁ I METODY}

Stosując model epidemiologicznego badania opisowego wykorzystano wtórne dane o liczbie zakażonych, liczbie zgonów i osób hospitalizowanych w związku z zakażeniem SARS-CoV-2. Źródłem informacji były dzienne raporty prowadzone przez Wojewódzką Stację Sanitarno-Epidemiologiczną w Katowicach i podległe jej stacje powiatowe. Dane te uwzględniają płeć, wiek i miejsce zamieszkania, a także prawdopodobne okoliczności zakażenia ustalone w trakcie dochodzenia epidemiologicznego. W pracy wzięto pod uwagę jedynie pierwszorazowe pozytywne wyniki testu wykonanego metodą RT-PCR w kierunku zakażenia wirusem SARS-CoV-2 u mieszkańców województwa śląskiego, w tym u pracowników przemysłu wydobywczego, zgromadzone w ramach tzw. badań przesiewowych. Analizowane dane, prezentowane $\mathrm{w}$ odniesieniu do poszczególnych powiatów, reprezentują okres od 05 marca do 18 sierpnia 2020 roku. Badanie będzie kontynuowane do lutego 2021, a ostateczne opracowanie zostanie uzupełnione o uzyskane wyniki.

\section{WYNIKI}

W analizowanym okresie zarejestrowano w woj. śląskim 19242 przypadki dodatnich testów molekularnych w kierunku zakażenia SARS-CoV-2. W tym czasie wykonano 390834 testy i tym samym odsetek pozytywnych testów wynosił 4,9\%. Dwukrotnie częściej wśród zakażonych znaleźli się mężczyźni niż kobiety, odpowiednio $64,7 \%$ i $35,3 \%$. Średni wiek osób z pozytywnym wynikiem testu wynosi $42,9+/-18,0$ lat, a mediana 41 lat.

Rycina 1 przedstawia odsetkowy udział zmarłych, ozdrowieńców i tzw. aktywnych przypadków wśród osób z dodatnim wynikiem testu RT-PCR (stan na 18.

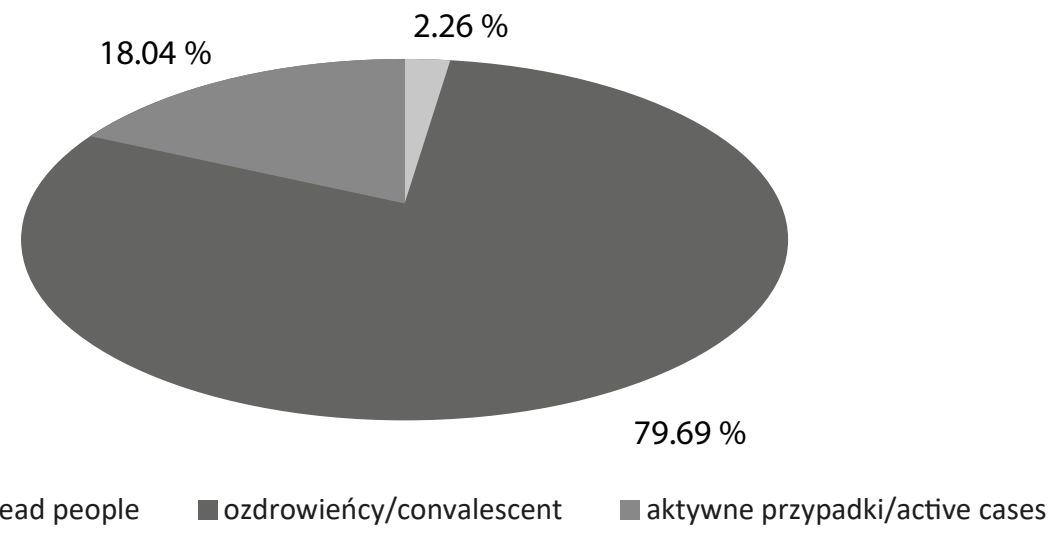

osoby zmarłe/dead people

ozdrowiency/convalescent

aktywne przypadki/active cases

Fig.1 The structure of people with a positive result of RT-PCR COVID test (as of 18.08.2020 year)

Ryc.1 Struktura osób z dodatnim wynikiem testu RT-PCR w kierunku COVID-19 (stan na dzień 18.08.2020 roku) 
in whom the infection continues, so it is the sum of all infections minus the number of convalescents and fatalities.

Most people with a positive test were convalescents (79.69\%) as of August 18, almost every fifth (18.04\%) was an active person (people with continues process of infection). Mortality due to COVID-19 (percentage of deaths among all people with a positive test) in the Silesian Voivodeship was $2.26 \%$, while the percentage of deaths due to COVID-19 among all tested people was $0.1 \%$.

In the case of $70.5 \%$ infected people, it was not possible to establish the circumstances (place) of the virus transmission. Infections that occurred in health care units (hospital or clinic) concerned only 5.3\% of cases. Another 3.3\% of people infected themselves in DPS (Social Welfare Home) or ZOL (Care and Therapeutic Facility). Every fifth infected person $(20.5 \%)$ declared to contact with a quarantined person (Fig. 2).
08. 2020). W odniesieniu do osób zakażonych wirusem SARS-CoV-2, na potrzeby nadzoru sanitarnego przyjęto, że ozdrowieńcy to osoby z dodatnim wynikiem, u których dwa kolejne, następujące po sobie wyniki testu RT-PCR były ujemne. Z kolei przypadki aktywne to osoby, u których infekcja wciąż trwa, a więc jest to suma wszystkich zakażeń pomniejszona o liczbe ozdrowieńców i ofiar śmiertelnych.

Większość osób z dodatnim wynikiem testu posiadała na dzień 18 sierpnia status ozdrowieńca $(79,69 \%)$, blisko co piąty $(18,04 \%)$ to osoba będąca aktywnym przypadkiem (z trwającą infekcją). Śmiertelność z powodu COVID-19 (odsetek zgonów wśród wszystkich osób z pozytywnym wynikiem testu) w woj. śląskim kształtowała się na poziomie $2,26 \%$, natomiast odsetek zmarłych z powodu COVID-19 wśród wszystkich osób przetestowanych w kierunku choroby kształtował się na poziomie $0,1 \%$.

W odniesieniu do $70,5 \%$ osób zakażonych nie udało się ustalić okoliczności (miejsca), w którym mogło dojść do transmisji wirusa. Zakażenia, które miały miejsce w zakładach opieki zdrowotnej (szpital lub przychodnia) dotyczyły jedynie 5,3\% przypadków. Kolejne 3,3\% osób zaraziło się w DPS (Dom Pomocy Społecznej) lub ZOL (Zakład Opiekuńczo Leczniczym). Co piąty zakażony (20,5\%) miał kontakt z osobą poddaną kwarantannie (Ryc. 2).

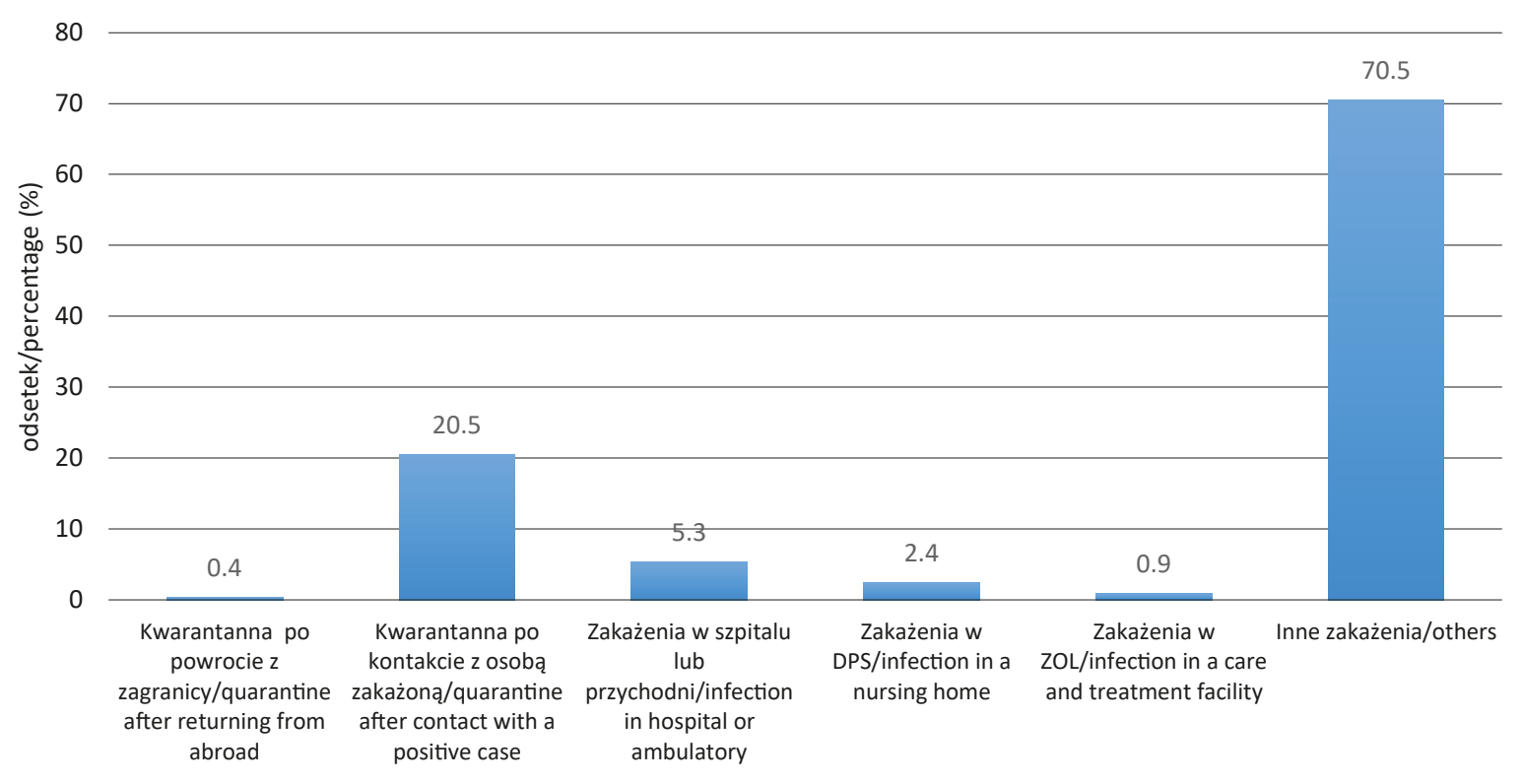

Fig. 2 The structure of COVID-19 infection circumstances in people with positive results of RT-PCR (value in \%) Ryc. 1 Struktura okoliczności zakażenia COVID-19 u osób z pozytywnym wynikiem testów wykonanych metodą RTPCR (wartości \%)

Figure 3 presents a cumulated number of positive tests in particular poviats of Silesian Voivodeship. In none of the subregion, the number of positive cases exceeded $2 \%$ of the population. The highest infection
Rycina 3 przedstawia skumulowane liczby dodatnich wyników testu w poszczególnych powiatach województwa śląskiego. W żadnym z powiatów liczba pozytywnych przypadków nie przekroczyła $2 \%$ 
rates (n / 100,000) were recorded in the Jastrzębski, Żorski, Wodzisławski, and Rybnik poviats, which was most likely related to screening tests conducted among employees of the mining industry, mainly miners working in these regions. The percentage of deaths due to COVID-19 did not exceed $0.05 \%$ of the populacji mieszkańców. Największe współczynniki zakażenia (n/100 000) odnotowano w powiatach jastrzębskim, żorskim, wodzisławskim i rybnickim, co miało najpewniej związek z badaniami przesiewowymi prowadzonymi w tych powiatach wśród pracowników przemysłu wydobywczego, głównie górników.

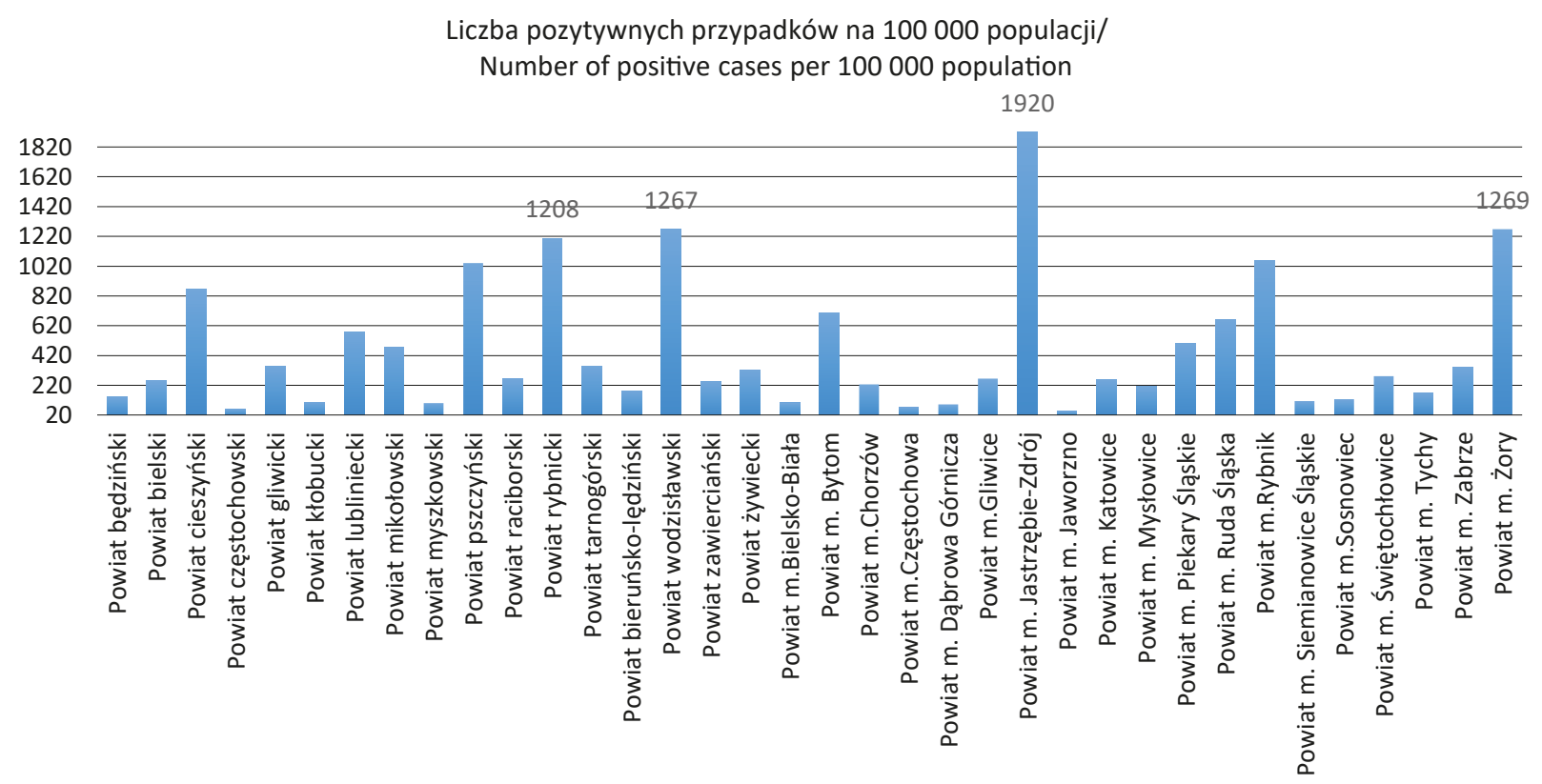

Fig. 3 Number of inhabitants with a positive result of PCR COVID-19 test in particular poviats of Silesian voivodeship (cumulated data from the beginning of pandemic)

Ryc. 2 Liczba mieszkańców populacji powiatów woj. śląskiego z dodatnim wynikiem testu PCR w kierunku COVID-19 (dane skumulowane od początku rejestracji pandemii)

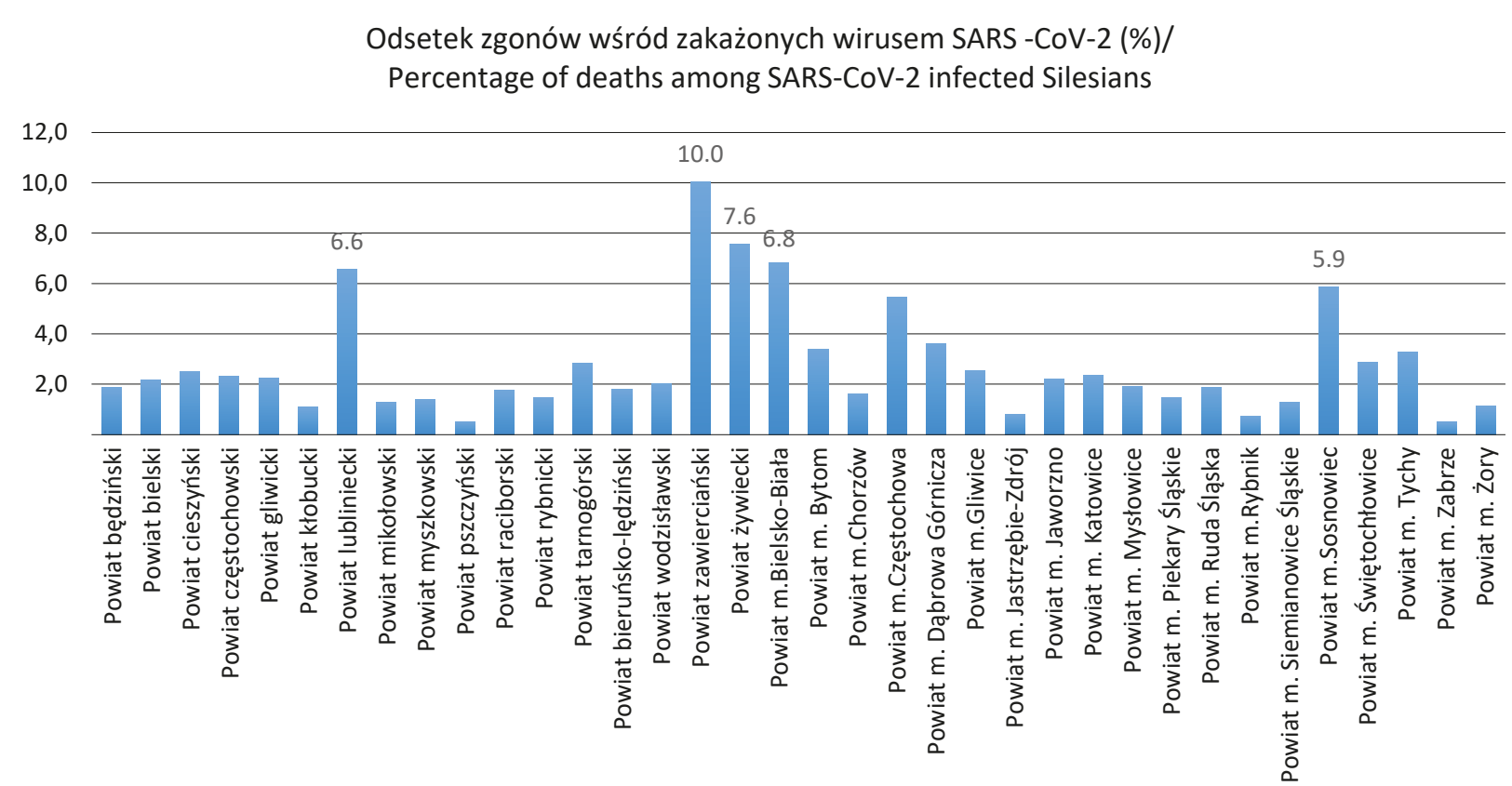

Fig. 4 Percentage of deaths due to COVID-19 among all positive SARS-CoV-2 cases in particular poviats of Silesian voivodeship (cumulated data from the beginning of pandemic)

Ryc. 3 Odsetek zgonów z powodu COVID-19 wśród wszystkich zakażonych SARS-CoV-2 mieszkańców woj. śląskiego według miejsca zamieszkania w poszczególnych powiatach 
total population in any of the poviats. However, the registered mortality rate varied considerably depending on the poviat, the highest value was achieved in the Zawiercie, and then in Żywiec, Lubliniec poviats, and the city of Bielsko-Biała (Fig. 4).

\section{DYSKUSJA}

Analysis of the secondary epidemiological data of COVID-19 in the Silesian Voivodeship allows for a preliminary estimation, among people with a positive molecular RT-PCR test, about $20 \%$ are people with the symptomatic form of COVID-10. Moreover, the disease leads to death, in about $2 \%$ of those who are infected. This information has to be handled with caution, because firstly it comes from data collected only until mid-August this year, and secondly, it relates to the results of the molecular test with a critical diagnostic window. Regardless of these limitations, it can be assumed that the acquired epidemiological picture is, on the global scale of the voivodeship, justified similar further analyses and comparisons leading to the definition of the epidemic dynamics.

Transfer of the obtained data to the level of particular poviats in the voivodship reveals a significant spatial variability of the coefficients. The size of observed differences is difficult to explain, not only due to the lack of data allowing in this case even the simplest cause-relationship analyses. Regardless of the limitations inherent in the descriptive study model, it is necessary to note the surprising size of this diversity, difficult to interpret even based on simple models of infectious disease transmission. Therefore, artifacts related to the use of secondary epidemiological data cannot be disregarded.

The data used in our analysis rather do not reflect the basic criterion of research representativeness. Due to the campaign of extensive screening tests involving miners, undertaken on the initiative of the Minister of Health and the Chief Sanitary Inspector at the beginning of May 2020 (7), it can be assumed that higher values of the percentage of the positive test are the result of this initiative. Moreover, this situation undoubtedly influenced the observed masculinization index in the group of positive cases confirmed by the RT-PCR method, as $64.7 \%$ of these groups were men. Similarly, in the group of hospitalized patients in Lombardy (82.0\%), the majority were men (8).

In the study, we noted a large spatial variability of mortality in poviats and the situation is similarly difficult to explain due to the descriptive nature of the analysis. Potential reasons for the variability include numerous factors and circumstances unavailable in the descriptive study. Perhaps the observed result could be an effect of the uneven allocation of infrastructure and
Odsetek zmarłych z powodu COVID-19 nie przekroczył wartości 0,05\% populacji ogółem w żadnym z powiatów. Jednakże zarejestrowany współczynnik śmiertelności był mocno zróżnicowany w zależności od powiatu, największą wartość osiągnął w powiecie zawierciańskim, a następnie żywieckim, lublinieckim i mieście Bielsko-Biała (Ryc. 4).

\section{DYSKUSJA}

Ogląd sytuacji epidemiologicznej COVID-19 w województwie śląskim na podstawie wtórnych danych epidemiologicznych, udostępnionych przez WSSE w Katowicach, pozwala na wstępne oszacowanie, że wśród osób z pozytywnym wynikiem molekularnego testu RT-PCR około 20 \% stanowią osoby z objawową postacią COVID-10, w tym chorobą wiodącą do zgonu u około $2 \%$ zakażonych. Ta informacja musi być traktowana w ostrożny sposób, albowiem po pierwsze pochodzi z danych gromadzonych do połowy sierpnia b.r., a po drugie odnosi się do wyników testu molekularnego, posiadającego ograniczone okno diagnostyczne. Niezależnie od tych zastrzeżeń można przyjąć, że pozyskany obraz epidemiologiczny jest, w globalnej skali województwa, podstawą do prowadzenia dalszych analiz tego typu oraz porównań umożliwiających opis dynamiki epidemii.

Przeniesienie pozyskanych danych na poziom poszczególnych powiatów w województwie ujawnia istotne zróżnicowanie terytorialne współczynników. Wielkość tego zróżnicowania jest trudna do wytłumaczenia, nie tylko ze względu na brak danych umożliwiających w tym przypadku chociażby najprostsze analizy przyczynowo-skutkowe. Abstrahując od ograniczeń wpisanych w model badania opisowego trzeba odnotować zaskakującą wielkość tego zróżnicowania, trudną do interpretacji nawet na gruncie prostych modeli transmisji choroby zakaźnej. Nie można zatem nie uwzględnić artefaktów związanych z używaniem wtórnych danych epidemiologicznych.

Wykorzystane w niniejszej analizie dane raczej nie spełniają podstawowego kryterium reprezentatywności badania. Bowiem z uwagi na akcję szeroko zakrojonych badań przesiewowych obejmujących górników, podjętą z inicjatywy Ministra Zdrowia oraz Głównego Inspektora Sanitarnego na początku maja 2020 roku (7) można przypuszczać, iż większe wartości współczynników dodatnich wyników testu są efektem właśnie tej inicjatywy. Ponadto sytuacja ta miała niewątpliwie wpływ na zaobserwowany wskaźnik maskulinizacji w grupie pozytywnych przypadków potwierdzonych metodą RT-PCR, wśród tych osób znalazło się bowiem 64,7\% mężczyzn. Podobnie, w grupie hospitalizowanych pacjentów w Lombardii (82\%) większość stanowili mężczyźni (8). 
human resources in the healthcare sector, which is also supported by the high respiratory mortality rates in the previous years (2017 and 2018), recorded in the poviats with the highest percentage of deaths due to COVID-19 among patients. The mortality rate of COVID-19 in the first half of the year (as of June 18, 2020), determined based on the sanitary inspection data, was at the level of $2.26 \%$ and was much lower than in many EU countries. For example, in Switzerland, it was 5.9\%, and in Portugal and Germany, it was slightly above $4 \%$ (9). The highest mortality was reported among COVID-19 patients in Belgium (15.8\%), Great Britain (15.1\%), France (14.7\%), and Italy (13.7\%). Regardless of the previously formulated doubts about the real significance of the mortality data, we couldn't ignore that the death rate exceeding 5\% was recorded in the Zawiercie (10.0\%), Żywiec (7.6\%), Lubliniec (6.6\%), and Bielsko-Biała (6.8\%).

A separate issue is the result of epidemiological investigations. It was noted that the circumstances of the infection were not established for $3 / 4$ cases $(70.5 \%)$, and every fifth case of infection was related to contact with another sick person during the quarantine. It is worth noting that in almost every tenth infection (8.6\%) there was a relationship with a treatment unit (clinic or hospital) or care unit (DPS or ZOL). It cannot be ruled out that the location of this type of facility in a given poviat correlated with the high mortality rate in this area, which results from the high risk of COVID-19 disease and death in the case of elderly people with comorbidity diseases (10).

The conclusion regarding the high territorial instability of the mortality rates is additionally supported by the confirmation of a large percentage of asymptomatic infections shaping low mortality rates. An additional mortality analysis would verify this hypothesis. Another important information concerns the significant percentage of convalescent $(79.6 \%)$ in the studied groups, which is consistent with the data observed in Germany $(80 \%)$ and similar to the situation in other EU countries (9). In general, the percentage of people with a positive test was at the level of $4.9 \%$ of all the first recognized cases in the Silesian Voivodeship and this level was slightly lower than that observed in the Republic of Korea (6.2\%) (11). Additionally, it is worth noting that the value recorded in the province Silesia is within the frequency range registered in other EU countries (9). The highest percentage of positive molecular tests in the comparable period was recorded in Spain (15\%) and Italy (9.8\%), and the lowest in Germany (2.7\%) and Portugal (1.1\%).

Similar to our study, spatial variability of the incidence defined on the positive results of RT-PCR test was recorded in Asian countries, the highest rates were noted in China $(55.0 / 100,000)$ and the Republic
W badaniu odnotowaliśmy duże terytorialne zróżnicowanie śmiertelności $\mathrm{w}$ powiatach i sytuacja podobnie jest trudna do wyjaśnienia ze względu na opisowy charakter przeprowadzonych analiz. Wśród potencjalnych przyczyn tego zróżnicowania można rozważać szereg niedostępnych w naszym badaniu czynników i okoliczności. Być może jest to efekt nierównomiernej alokacji infrastruktury i zasobów ludzkich w sektorze opieki zdrowotnej, za czym przemawiają także wysokie współczynniki umieralności z przyczyn oddechowych w latach wcześniejszych (2017 i 2018), odnotowane w powiatach o największym odsetku zmarłych z powodu COVID-19 wśród chorych. Ustalony na podstawie danych WSSE współczynnik śmiertelności w przebiegu COVID-19 w pierwszej połowie roku (stan na 18 czerwca 2020 roku) kształtował się na poziomie 2,26\% i był zdecydowanie mniejszy niż w wielu krajach EU. Na przykład w Szwajcarii wynosił on $5,9 \%$, a w Portugalii i Niemczech nieco przekraczał wartość 4\% (9). Największa śmiertelność dotyczyła chorych na COVID-19 mieszkańców Belgii (15,8\%), Wielkiej Brytanii (15,1\%) oraz Francji (14,7\%) i Włoch (13,7\%). Niezależnie od wcześniej formułowanych wątpliwości odnośnie rzeczywistego znaczenia danych o śmiertelności nie można zignorować faktu, że współczynnik śmiertelności przekraczający $5 \%$ odnotowano w powiatach zawierciańskim $(10,0 \%)$, żywieckim $(7,6 \%)$, lublinieckim $(6,6 \%)$ oraz w mieście Bielsko-Biała (6,8\%).

Osobną kwestię stanowi wynik dochodzeń epidemiologicznych. Okazało się, że w odniesieniu do $3 / 4$ przypadków $(70,5 \%)$ nie ustalono okoliczności zakażenia, a co piąty przypadek wskazywał na zakażenie $\mathrm{w}$ trakcie odbywania kwarantanny z inną osobą chorą. Na uwagę zasługuje fakt, iż w odniesieniu prawie co dziesiątego zakażenia $(8,6 \%)$ odnotowano związek z jednostką leczniczą (przychodnia lub szpital) lub opiekuńczą (DPS lub ZOL). Nie można przy tym wykluczyć, że lokalizacja tego typu zakładów na terenie danego powiatu korelowała z poziomem umieralności na tym obszarze, co wynika z dużego ryzyka zachorowania na COVID-19 i zgonu z tego powodu w przypadku osób w podeszłym wieku i obciążonych wielochorobowością (10).

Wniosek odnośnie dużej terytorialnej niestabilności rejestrowanych współczynników śmiertelności jest dodatkowo poparty stwierdzeniem dużego odsetka bezobjawowych zakażeń, kształtującego tym samym niskie współczynniki śmiertelności. Dodatkowa analiza umieralności pozwoliłaby na weryfikację tej hipotezy. Inna istotna informacja dotyczy znacznego odsetka ozdrowieńców $(79,6 \%)$ w badanych grupach, co jest zbieżne z danymi obserwowanymi w Niemczech $(80 \%)$ oraz podobne do sytuacji w innych krajach EU (9). 
of Korea $(61.4 / 100,000)(12)$. The values reported in other EU countries also differ, from the value of 197.8 / 100,000 in Germany to the value of 465 / 100,000 in Spain (9). Nevertheless, the values recorded in some poviats in the Silesia region were higher due to the already mentioned mass screening tests of miners.

It can be concluded that the current epidemic situation in the Silesian voivodeship noted in our study mostly depends on factors related to the nature of the analyzed data. It cannot be assumed that they represent systematic monitoring of the epidemic, rather they reflect the effects of research conducted with varying intensity in the region, which are not verified in terms of credibility. In other words, the obtained results of the analysis are biased by the secondary nature of epidemiological data. This significant limitation hinders the assessment of revealed spatial variability of the COVID-19 epidemic in the Silesian voivodeship but does not completely disqualify the desirability of testing. They are justified, inter alia, by important social considerations and they help in enable administrative decisions regarding the implementation of sanitary and epidemiological restrictions in a particular poviat. Another issue is the result of the cost-benefit analysis of the current preventive actions, which, however, is beyond the aim of this report. Finally, it must be stated that the currently implemented program should be supplemented with a systematic assessment of the population prevalence and course of COVID-19 infection referring to good epidemiological practice. This type of research, supplemented by reliable data from health care institutions, is conducted in many countries, including as part of the 'Solidarity II' scientific initiative (13).

\section{CONCLUSIONS}

The results of antigenic molecular tests for SARSCoV-2 virus in the Silesian Voivodeship indicate that in the first half of 2020, the infection rate was approximately $5 \%$, and the frequency of symptomatic form of the disease was approximately $20 \%$. The analysis of the spatial variability of the frequency of infection and mortality reveals significant differences between particular poviats in the occurrence of both phenomena, but their explanation is not possible due to the descriptive nature of the analysis and the so-called secondary form of epidemiological data. The observed COVID-19 situation justifies the purposefulness and necessity of monitoring the epidemic using representative primary data, including data obtained from sero-epidemiological studies.
Generalnie, odsetek osób z pozytywnym wynikiem testu kształtował się na poziomie 4,9\% wszystkich pierwszorazowo badanych w woj. śląskim i poziom ten był nieco mniejszy niż obserwowany w Republice Korei $(6,2 \%)$ (11). Dodatkowo warto zauważyć, że wartość odnotowana $\mathrm{w}$ woj. śląskim mieści się w zakresie częstości rejestrowanych w innych krajach EU (9). Największy odsetek dodatnich testów molekularnych, w porównywalnym okresie, notowano w Hiszpanii $(15 \%)$ i Włoszech $(9,8 \%)$, a najmniejszy w Niemczech $(2,7 \%)$ oraz Portugalii $(1,1 \%)$.

Podobne, co w naszym badaniu zróżnicowanie w zakresie zapadalności definiowanej na podstawie wyniku testu RT-PCR odnotowano w krajach azjatyckich, największe wskaźniki dotyczyły Chin (55,0/100 000) i Republiki Korei (61,4/100 000) (12). Zróżnicowane są także wartości raportowane w innych krajach EU, od wartości 197,8/100 $000 \mathrm{w}$ Niemczech do wartości 465/100 000 w Hiszpanii (9). Niemniej jednak wartości zarejestrowane w niektórych powiatach na Śląsku były większe z uwagi na wspomniane już masowe wykonywanie badań przesiewowych wśród górników. Można uznać, iż odnotowana przez nas aktualna sytuacja epidemiczna w województwie śląskim w dużej mierze zależy od czynników związanych z charakterem analizowanych danych. Nie można przyjąć, że reprezentują one systematyczne działania monitoringowe, w zakresie skumulowanych wartości odzwierciedlają skutki badań prowadzonych ze zróżnicowanym natężeniem na terenie powiatu, nie są weryfikowane pod kątem wiarygodności. Innymi słowy wyniki przeprowadzonej analizy są obarczone zniekształceniem, które należy przypisać specyfice wtórnych danych epidemiologicznych. To istotne ograniczenie utrudnia w znacznym stopniu ocenę terytorialnego zróżnicowania epidemii COVID-19 w województwie śląskim, ale nie dyskwalifikuje całkowicie celowości wykonanych badań. Są one uzasadnione między innymi ważnymi względami społecznymi, a ponadto umożliwiają podejmowanie decyzji administracyjnych odnośnie wdrożenia restrykcji sanitarno-epidemiologicznych na terenie danego powiatu. Inną kwestią jest wynik analizy uwzględniającej bilans kosztów i korzyści prowadzonego programu, co jednakże wykracza poza przedmiot niniejszego doniesienia. Wreszcie, trzeba stwierdzić, że prowadzony aktualnie program powinien być uzupełniany systematyczną i odwołującą się do dobrej praktyki epidemiologicznej oceną populacyjnego rozpowszechnienia i przebiegu zakażenia wirusem COVID-19. Tego typu badania, uzupełnione wiarygodnymi danymi z instytucji ochrony zdrowia, są prowadzone w wielu krajach, między innymi w ramach inicjatywy naukowej 'Solidarity II' (13). 


\section{REFERENCES}

1. WHO. Public health surveillance for COVID-19. Interim guidance. 07.08 2020. Dostęp: https:// www.who.int/publications/i/item/who-2019nCoV-surveillanceguidance-2020.7, cytowany 11.09.2020

2. Agencja Badań Medycznych. Pacjenci w badaniach klinicznych. Dostęp: https:// pacjentwbadaniach.abm.gov.pl/pwb/aktualnosci/ aktualne-wydarzenia-i-i/380,Od-11-czerwca2020-Ministerstwo-Zdrowia-zmienia-formuleraportowania-danych-doty.html, cytowany 11.09.2020

3. Gęstość zaludnienia w 2019 roku. Bank Danych Lokalnych GUS. Dostęp: https://bdl.stat.gov.pl/ BDL/dane/podgrup/tablica, cytowany 11.09.2020

4. Katowice Airport. Statystyki roczne. Całkowity ruch pasażerski. Dostęp: https://www.katowiceairport.com/pl/nasze-lotnisko/statystyki/ statystyki-roczne, cytowany 11.09.2020

5. Urząd Statystyczny w Katowicach. Ludność, ruch naturalny i migracje $\mathrm{w}$ województwie śląskim w 2019 r. Dostęp: https://katowice.stat. gov.pl/publikacje-i-foldery/ludnosc/ludnosc-ruchnaturalny-i-migracje-w-wojewodztwie-slaskim-w2019-r-,2,18.html, cytowany 11.09.2020

6. European Centre for Disease Prevention and Control. Transmission of COVID-19. Dostęp: https://www.ecdc.europa.eu/en/covid-19/latestevidence/transmission, cytowany 11.09.2020

7. Śląski Urząd Wojewódzki w Katowicach. Ruszyły badania przesiewowe górników. Dostęp: https:// www.katowice.uw.gov.pl/aktualnosci/ruszylybadania-przesiewowe-gornikow, 17.09.2020

cytowany

8. GrasselliG,ZangrilloA,ZanellaA, etal.,COVID-19 Lombardy ICU Network. Baseline Characteristics and Outcomes of 1591 Patients Infected With SARS-CoV-2 Admitted to ICUs of the Lombardy Region, Italy. JAMA 2020 28;323(16):1574-1581. doi: 10.1001/jama.2020.5394. Dostęp: https:// pubmed.ncbi.nlm.nih.gov/32250385/, cytowany 20.09.2020

9. Pericàs JM, Hernandez-Meneses $\mathrm{M}$, et al. COVID-19: from epidemiology to treatment. Eur Heart J. 2020 Jun 7; 41(22): 2092-2112. Dostęp: https://europepmc.org/article/med/32511724, cytowany 30.09 .2020

10. Ortiz-Prado E, Simbaña-Rivera K, Gómez-Barreno L,et al. Clinical, molecular, and epidemiological characterization of the SARS-CoV-2 virus and the Coronavirus Disease 2019 (COVID-19), a comprehensive literature review. Diagnostic Microbiology and Infectious Disease, 2020, 98(1), 115094. Dostęp: https://www.sciencedirect.com/ science/article/pii/S0732889320304715, cytowany 30.09.2020

\section{WNIOSKI}

Wyniki antygenowych badań molekularnych w kierunku zakażenia wirusem SARS-CoV-2 w województwie śląskim wskazują, że w pierwszym półroczu 2020 roku częstość zakażenia kształtowała się na poziomie około $5 \%$, a częstość objawowej postaci choroby na poziomie około $20 \%$. Analiza częstości zakażenia oraz śmiertelności w układzie terytorialnym województwa (powiaty) ujawnia duże zróżnicowanie występowania obu zjawisk, przy czym wyjaśnienie tego zróżnicowania nie jest możliwe ze względu na opisowy charakter analizy oraz tzw. wtórną postać danych epidemiologicznych. Uzyskany obraz epidemiczny uzasadnia celowość i konieczność monitorowania epidemii z wykorzystaniem tzw. pierwotnych reprezentatywnych danych, w tym danych pozyskiwanych w toku badań sero-epidemiologicznych.

11. The Korean Academy of Medical Sciences. Report on the Epidemiological Features of Coronavirus Disease 2019 (COVID-19) Outbreak in the Republic of Korea from January 19 to March 2, 2020. J Korean Med Sci. 2020,16;35(10):e112. Dostęp: https://jkms.org/DOIx.php?id=10.3346/ jkms.2020.35.e112, cytowany 20.09.2020

12. Chih-Cheng Lai, Cheng-Yi Wang, Ya-Hui Wang, et al. Global epidemiology of coronavirus disease 2019 (COVID-19): disease incidence, daily cumulative index, mortality, and their association with country healthcare resources and economic status. Int J Antimicrob Agents. 2020; 55(4): 105946. Dostęp: https://www.ncbi.nlm.nih.gov/ pmc/articles/PMC7156123/, cytowany 20.09.2020

13. 'Solidarity II' global serologic study for COVID-19, Dostęp: https://www.who.int/emergencies/diseases/ novel-coronavirus-2019/global-research-onnovel-coronavirus-2019-ncov/solidarity-2-globalserologic-study-for-covid-19, cytowany 20.09.2020

Received: $12.10 .2020 \mathrm{r}$. Otrzymano: 12.10.2020 r.

Accepted for publication: $26.10 .2020 \mathrm{r}$.

Zaakceptowano do publikacji: 26.10.2020 r.

\section{Address for correspondence: Adres do korespondencji:}

Małgorzata Kowalska

Katedra i Zakład Epidemiologii

Wydział Nauk Medycznych w Katowicach

Śląski Uniwersytet Medyczny

40-752 Katowice

ul. Medyków 18

Adres e-mail: mkowalska@sum.edu.pl

Tel. 322088543 